\title{
PEMBIAYAAN SISTEM BAGI HASIL LEMBAGA KEUANGAN SYARIAH PADA USAHA MIKRO KECIL DAN MENENGAH (UMKM) DI KABUPATEN JEMBER
}

\author{
Mohammad Dio Awaludin Jauhar ${ }^{1}$ \\ Email: djauhar.hmja@gmail.com
}

\begin{abstract}
Ahmad Roziq ${ }^{2}$
Abstract

This study aims to know the implementation of "pembiayaan bagi hasil" conducted by the islamic financial institutions including the type of financing given outcomes, the problems during the implementation from the islamic financial instituitons and partners view. This study is a qualitative research with multi-case studies approach, the research examines two or more subjects, background, or storage of research data. Stages of research conducted field study/survey is used to find the problem of financing system in Islamic Financial Institutions and their partners. The result shows that overall of seven islamic financial institutions have "pembiayaan bagi hasil" and Musyarakah financing as one of their products in providing services to their business partners. But it its implementation, there are three main problems, they are the lack of financial statement reports, the side streams, and asymetry of information. From the problem, researches gives some solutions, the first is the partner need a mentoring about financial statement report periodically, raise public awareness about honesty culture, and improve the quality and quantity of human resources on islamic financial institutions.
\end{abstract}

Keyword: Profit Loss Sharing, Islamic Financial Institutions, SMEs

\section{PENDAHULUAN}

Sejak krisis moneter "merontokkan" perekonomian nasional, tidak diragukan lagi UMKM adalah penyelamat, sehingga proses pemulihan ekonomi dapat dilakukan. UMKM mendorong pertumbuhan ekonomi dan penyerapan tenaga kerja yang tidak dapat dilakukan usaha besar. UMKM dalam menyerap tenaga kerja di Indonesia cukup besar, yaitu sebanyak $97,3 \%$ dari total angkatan kerja yang bekerja. Data Badan Pusat Statistik (BPS) mencatat jumlah usaha mikro, kecil dan menengah (UMKM) di Indonesia tahun 2014 adalah lebih dari 57.900.000 (lima puluh tujuh juta Sembilan ratus ribu rupiah) unit, dan merupakan unit usaha terbesar dari total

\footnotetext{
${ }^{1}$ Corresponding Author: PT. GG group Surabaya.

${ }^{2}$ Jurusan Akuntansi,, Fakultas Ekonomi dan Bisnis, Universitas Jember, Jl. Kalimantan No. 37 Jember 68121
} 
unit usaha yang ada dengan memberi kontribusi terhadap PDB 58,92 persen. Ini menandakan bahwa usaha mikro, kecil dan menengah (UMKM) memiliki peran yang penting terutama dalam memperluas lapangan kerja, meningkatkan pendapatan masyarakat sehingga dapat menjadi penggerak pembangunan dan pertumbuhan ekonomi. Sektor usaha mikro, kecil dan menengah sangat berperan penting dalam pertumbuhan perekonomian di Indonesia. Namun, pertumbuhan dan perkembangan usaha mikro dan kecil di Indonesia saat ini belum sepenuhnya diimbangi peningkatan kualitas UMKM yang ada. Hal ini karena masih ada kendala terbesar yang di hadapi dalam mengembangkan usaha, yaitu keterbatasan modal (www.kemenkop.go.id). Rendahnya permodalan merupakan salah satu ciri utama UMKM, karena UMKM masih dijalankan sebagai pekerjaan sampingan, sehingga orientasi pasar menjadi terbatas. UMKM seharusnya jangan dianggap sebagai usaha sampingan, sehingga produk yang dihasilkan tidak saja dipasarkan secara dosmetik tetapi juga mampu bersaing dengan pasar global. Jika UMKM memiliki modal cukup, maka dapat dilakukan ekspansi pasar dan riset produk, sehingga mampu bersaing dengan produk sejenis dari negara lain (Susilo 2012).

Lembaga keuangan syariah yang saat ini hadir sebagai wujud perkembangan aspirasi bagi masyarakat yang menginginkan kegiatan perekonomian dengan berdasarkan prinsip syariah, selain lembaga keuangan konvensional yang telah berdiri selama ini. Lembaga keuangan syariah tersebut diantaranya adalah bank syariah dan Baitul Maal wat Tamwil (BMT) atau lembaga keuangan mikro syariah. Ada dua metode pembiayaan yang diterapkan di bank syariah, yaitu metode nonprofit loss sharing (non-PLS) berupa pembiayaan dengan sistem jual beli termasuk sewa beli dan metode profit loss sharing (PLS) berupa pembiayaan dengan sistem bagi-hasil. Menurut Triyuwono (2004) dalam sistem bagi hasil, tingkat bunga diganti dengan tingkat laba, oleh karena itu sistem investasi didorong oleh tingkat laba, ketika tingkat laba lebih tinggi maka total investasi juga lebih tinggi. Sehingga tingkat laba yang positif dapat mengeliminasi permintaan uang spekulatif, tingkat inflasi dapat dikurangi, karena hanya ada permintaan aktual untuk investasi riil.Secara umum prinsip bagi hasil dapat dilakukan dalam empat akad, yaitu mudharabah, musyarakah, muzara'ah, dan musaqah. Namun dalam praktiknya akad yang paling banyak dipakai adalah mudharabah dan musyarakah.

Pembiayaan dengan akad mudharabah dan musyarakah pada dasarnya merupakan pembiayaan yang sempurna, hal ini dikarenakan pada pembiayaan tersebut digunakan prinsip bagi hasil keuntungan (profit sharing). Selain menggunakan prinsip bagi hasil keuntungan (profit sharing), hal lain yang membuat ideal adalah adanya pembagian kerugian (loss sharing). Kerugian pada pembiayaan dengan akad mudharabah akan ditanggung sepenuhnya oleh bank, kecuali bila mitra usaha melakukan kelalaian dan kesengajaan yang menyebabkan dialaminya kerugian. Kerugian pada pembiayaan dengan akad musyarakah akan dihitung sesuai dengan porsi modal masing-masing pihak, yaitu pihak bank dan mitra usaha. Pada dasarnya dengan prinsip bagi kerugian (loss sharing) ini, maka kedua pihak yaitu pihak mitra usaha dan pihak bank akan berusaha untuk menghindari terjadinya kerugian tersebut. Mereka akan bekerjasama guna menghindari terjadinya kerugian usaha mereka, mitra usaha akan bekerja keras dalam mengembangkan usahanya, di sisi lain pihak bank memberikan pembinaan dan pengawasan dalam usaha tersebut. Jember sebagai salah satu kota di Jawa Timur yang memiliki UMKM yang banyak yakni sejumlah 1387 unit yang terdaftar di Dinas Koperasi dan UMKM. 
Pertumbuhan UMKM di Kabupaten Jember (www.diskop.jatim.go.id), diklaim menjadi yang terbesar untuk wilayah Propinsi Jawa Timur. Bahkan, Kabupaten Jember disebutkan mampu menyumbang pertumbuhan sebesar $6,2 \%$, dari total seluruh UMKM di Propinsi di Jawa Timur pada tahun 2014. Hal ini menunjukan bahwa iklim usaha yang ada di Jember sangat dinamis dan diikuti juga dengan perkembangan lembaga-lembaga perbankan dalam menopang UMKM tersebut dari sisi permodalan/pembiayaannya.

\section{TINJAUAN PUSTAKA}

\subsection{Lembaga Keuangan Syariah}

Lembaga keuangan syariah menurut Dewan Syariah Nasional adalah lembaga keuangan yang mengeluarkan produk keuangan syariah dan yang mendapat ijin operasional sebagai lembaga keuangan syariah. Definisi ini menegaskan bahwa suatu lembaga keuangan syariah harus memenuhi dua unsur yaitu unsur kesesuaian dengan syariah islam dan unsur legalitas operasi sebagai lembaga keuangan. Dalam operasionalnya, Lembaga Keuangan Syariah berada dalam koridor-koridor prinsipprinsip:

a. Keadilan, yakni berbagi keuntungan atas dasar penjualan riil sesuai kontribusi dan resiko masing-masing pihak.

b. Kemitraan, yang berarti posisi nasabah investor (penyimpan dana), dan pengguna dana, serta lembaga keuangan itu sendiri, sejajar sebagai mitra usaha yang saling bersinergi untuk memperoleh keuntungan.

c. Transparansi, lembaga keuangan Syariah akan memberikan laporan keuangan secara terbuka dan berkesinambungan agar nasabah investor dapat mengetahui kondisi dananya.

d. Universal, yang artinya tidak membedakan suku, agama, ras, dan golongan dalam masyarakat sesuai dengan prinsip Islam sebagai rahmatan lil alamin.

Berikut ini merupakan sistem operasional yang dilakukan oleh lembaga keuangan syariah:

Penghimpunan Dana, sebagaimana pada bank konvesional, penghimpunan dana di bank umum syariah dapat berbentuk giro, tabungan dan deposito. Namun demikian mekanisme operasional penghimpunan dana ini harus disesuaikan dengan prinsip syariah

Penyaluran Dana, dalam penyaluran dana bank syariah harus berpedoman kepada prinsip kehati-hatian. Sehubungan dengan hal itu bank diwajibkan untuk meneliti secara seksama calon nasabah penerima dana berdasarkan azas pembiayaan yang sehat. Ketentun-ketentuan lain yang berkaitan dengan penyaluran dana perbankan tetap berlaku sepanjang tidak bertentangan dengan prinsip syariah.

Jasa Perbankan, bank syariah dapat melakukan berbagai pelayanan jasa perbankan kepada nasabah dengan mendapat imbalan berupa fee atau komisi.

Fungsi Sosial, kepedulian social merupakan salah satu fungsi dan pembeda dari bank konvesional yang fungsi social ini tidak terpisahkan dari perbankan syariah. Fungsi bank syariah sebagai lembaga Baitul Maal yang menerima dan menyalurkan dana kebajikan.Fungsi sosial perbankan syariah adalah mengumpulkan dana zakat, infaq, shadaqah dan wakaf. Sektor ini menjamin terjadinya aliran kekayaan dari kelompok kaya kepada kelompok miskin, sehingga angka kesenjangan pendapatan dan kemiskinan masyarakat diharapkan dapat dikurangi. 


\subsection{Pembiayaan}

Aktivitas yang paling penting dalam dunia perbankan adalah pembiayaan atau financing karena pembiyaana adalah sumber pendapatan utama dan penunjang kelangsungan usaha bagi bank. Pembiayaan dalam bank syariah yang sesuai dengan hukum islam akan berbeda dengan bank konvensional. Pengertian pembiayaan dalam konteks bank syariah yang tercantum dalam UU No. 21 Tahun 2008: "penyediaan dana atau tagihan yang dipersamakan dengan itu, berupa transaksi bagi hasil dalam bentuk mudharabah dan musyarakah; transaksi sewa-menyewa dalam bentuk ijarah atau sewa beli dalam bentuk ijarah muntahiya bittamlik; transaksi jual beli dalam bentuk piutang mudharabah, salam dan istishna'; transaksi pinjam meminjam dalam bentuk qardh; dan transaksi sewa menyewa jasa dalam bentuk ijarah untuk transaksi multijasa, berdasarkan persetujuan atau kesepakatan antara bank syariah dan UUS dan pihak lain yang mewajibkan pihak yang dibiayai atau diberi fasilitas untuk mengembalikan dana tersebut dengan imbalan ujrah, tanpa imbalan atau bagi hasil."

Menurut Antonio (2001) pembiayaan pada perbankan syariah dibagi berdasarkan sifat penggunaanya menjadi:

a. Pembiayaan produktif, yaitu pembiayaan yang ditujukan untuk memenuhi kebutuhan produksi dalam arti luas, yaitu untuk peningkatan usaha baik usaha produksi, perdagangan, maupun investasi. Menurut keperluannya pembiayaan produktif dibagi menjadi dua:

1. Pembiayaan modal kerja, yaitu pembiayaan yang mempunyai tujuan untuk memenuhi kebutuhan: peningkatan produksi baik secara kuantitatis (jumlah produksi) maupun secara kualitas (mutu hasil produksi); untuk keperluan perdagangan atau peningkatan utility of place dari suatu barang. Unsur-unsur modal kerja terdiri atas komponen-komponen alat likuid (cash), piutang dagang (receivable) dan persediaan (inventory) yang umumnya terdiri atas persediaan bahan baku (raw materials), persediaan barang jadi (finished goods). Oleh karena itu pembiayaan modal kerja merupakan salah satu atau kombinasi dari pembiayaan likuiditas (cash financing), pembiayaan piutang (receivable financing) dan pembiayaan persediaan (inventory financing). Termasuk dalam jenis ini adalah al-mudharabah (kerjasama pemilik modal dan pengusaha) dan al-musyarakah (bagi hasil berserikat) yang menggunakan sistem bagi hasil.

2. Pembiayaan investasi, merupakan pembiayaan yang diberikan kepada mitra usaha untuk keperluan penambahan modal guna mengadakan rehabilitasi, perluan usaha, ataupun pendirian proyek baru. Adapun ciri-ciri pembiayaan investasi adalah untuk pengadaan barang-barang modal, mempunyai perencanaan alokasi dana yang matang dan terarah dan pembiayaan investasi biasanya untuk pembiayaan berjangka waktu menengah dan panjang. Termasuk dalm jenis ini adalah: al-musyarakah dan al-ijarah al munthia bittamlik.

3. Pembiayaan konsumtif, yaitu pembiayaan yang digunakan untuk memenuhi kebutuhan konsumtif yang akan habis digunakan untuk memenuhi kebutuhan. Pembiayaan ini biasanya untuk pemenuhan kebutuhan primer yaitu kebutuhan yang berupa barang baik itu makanan, minuman, pakaian dan tempat tinggal maupun jasa seperti pendidikan lebih tinggi, pelayanan kesehatan, pariwisata, hiburan dan sebagainya. Termasuk dalam pembiayaan ini adalah al-qardhul hasan, al-ba'i bithaman ajil, musyarakah dan ar-rahn. 


\subsection{Bagi Hasil}

Bagi hasil adalah bentuk perolehan kembalian atas kontrak investasi yang telah dilakukan dengan pihak bank syariah. Secara terminologi, profit sharing dalam kamus ekonomi diartikan pembagian laba. Secara definitif, menurut Antonio (2010, 138) profit sharing diartikan "bagi hasil adalah suatu sistem pengelolaan dana dalam perekonomian islam yakni pembagian hasil usaha antara pemilik modal (shohibul maal) dan pengelola modal (mudharib)". Menurut Syafi'i (2005) juga mengatakan bahwa bagi hasil adalah keuntungan/hasil yang diperoleh dari pengelolaan dana baik investasi maupun transaksi jual beli yang diberikan kepada mitra usaha dengan persyaratan.Pembolehan bagi hasil didalam ketentuan hukum islam didasarkan pada perbuatan Nabi Muhammad SAW dan juga pernah dipraktekan oleh para sahabat beliau. Sebagaimana hadits yang diriwayatkan oleh Al-Bukhari dari Abi Ja'far yang artinya “dari Qays bin Muslim, dari Abi Ja'far berkata: tidak ada penduduk kota Madinah dari kalangan Muhajirin kecuali mereka menjadi petani dan mendapatkan sepertiga atau seperempat" (HR. Bukhari). Oleh karena itu, dapat disimpulkan bahwa perjanjian bagi hasil ini tidak bertentangan dengan ketentuan hukum Islam, bahkan Rasulullah SAW beserta para sahabatnya pernah mengadakan perjanjian bagi hasil.

Menurut Anshori (2018, 138) "metode perhitungan bagi hasil terdiri dari metode profit and loss sharing, metode profit sharing dan metode revenue sharing".

a. Metode Profit and Loss Sharing

Sistem profit and loss sharing dalam pelaksanaanya merupakan bentuk dari perjanjian kerjasama antara pemodal (investor) dan pengelola modal (entrepreneur) dalam menjalankan kegiatan usaha ekonomi, dimana diantara keduanya akan terikat kontrak bahwa di dalam usaha tersebut jika mendapat keuntungan akan dibagi kedua pihak sesuai nisbah kesepakatan di awal perjanjian, dan begitu pula bila usaha mengalami kerugian akan ditanggung bersama sesuai porsi masing-masing. Keuntungan yang didapat dari hasil usaha tersebut akan dilakukan pembagian setelah dilakukan perhitungan terlebih dahulu atas biaya-biaya yang telah dikeluarkan selama proses usaha. Keuntungan yang dibagikan adalah keuntungan bersih (net profit) yang merupakan lebihan dari selisih atas pengurangan total cost terhadap total revenue.

b. Metode Profit Sharing

Profit sharing menurut etimologi Indonesia adalah bagi keuntungan. Dalam kamus ekonomi diartikan pembagian laba. Profit secara istilah adalah perbedaan yang timbul ketika total pendapatan (total revenue) suatu perusahaan lebih besar dari biaya total (total cost). Di dalam istilah lain profit sharing adalah perhitungan bagi hasil didasarkan kepada hasil bersih dari total pendapatan setelah dikurangi dengan biaya-biaya yang dikeluarkan untuk memperoleh pendapatan tersebut.

c. Metode Revenue Sharing

Revenue sharing berarti pembagian hasil, penghasilan atau pendapatan. Revenue (pendapatan) dalam kamus ekonomi adalah hasil uang yang diterima oleh suatu perusahaan dari penjualan barang-barang (goods) dan jasa-jasa (services) yang dihasilkannya dari pendapatan penjualan (sales revenue). Dalam arti lain revenue merupakan besaran yang mengacu pada perkalian antara jumlah output yang dihasilkan dari kegiatan produksi dikalikan dengan barang atau jasa dari suatu produksi tersebut. 


\subsection{Pembiayaan Bagi Hasil}

Pembiayaan terhadap mitra usaha berdasar prinsip bagi hasil sebagaimana disebutkan di dalam Pasal 1 angka 12 UU No. 10 Tahun 1998, bahwa: "Pembiayaan berdasarkan prinsip syariah adalah penyediaan uang atau tagihan yang dipersamakan dengan itu berdasarkan persetujuan atau kesepakatan antara bank dengan pihak lain yang mewajibkan pihak yang dibiayai untuk mengembalikan uang atau tagihan tersebut setelah jangka waktu tertentu dengan imbalan atau bagi hasil."

Dalam transaksi keuangan syariah, mekanisme bagi hasil diharapkan dapat menggantikan mekanisme bunga. Mekanisme bagi-hasil ini merupakan core product bagi lembaga keuangan syariah, seperti bank syariah. Sebab bank syariah secara eksplisit melarang penerapan tingkat bunga pada semua transaksi keuangan. Sistem bagi-hasil diyakini sebagai alat penghapus sistem bunga (Siddiqui et al. 2005). Pembiayaan dengan prinsip bagi hasil antara lain:

a. Pembiayaan Mudharabah

Menurut Antonio (2001, 95) dan Adiwarman (2004, 93) mendefinisikan mudharabah sebagai akad kerjasama antara dua pihak dimana pihak pertama (shahibulmaal) menyediakan modal, sedangkan pihak lainnya menjadi pengelola (mudharib). Keuntungan usaha secara mudharabah dibagi menurut kesepakatan yang dituangkan dalam kontrak, sedangkan apabila rugi ditanggung oleh pemilik modal selama kerugian itu bukan akibat kelalaian si pengelola. Apabila karena kesalahan pengelola maka si pengelola harus bertanggungjawab atas kerugian tersebut.

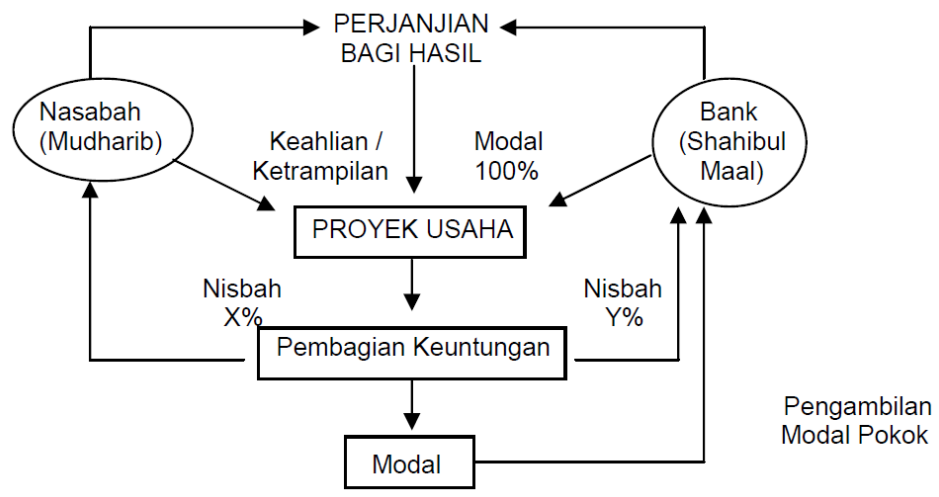

Gambar 2.1 Skema Pembiayaan Mudharabah

Prinsip bagi hasil berdasar perjanjian al mudharabah sebagaimana tersebut dalam skema di atas, menunjukkan suatu hubungan hukum antara dua pihak yaitu pihak bank (shahibul maal) sebagai penyedia dana dengan mitra usaha (mudharib) sebagai pihak pengelola dana. Hubungan hukum tersebut akan menimbulkan akibat hukum yaitu adanya hak dan kewajiban maupun tanggung jawab pada masing-masing pihak. Prinsip-prinsip bagi hasil berdasar perjanjian al mudharabah, terkait dengan pembiayaan terhadap mitra usaha yaitu dapat tercermin dari hak dan kewajiban masing-masing pihak yaitu pihak bank (shahibul maal) dengan pihak mitra usaha pengelola dana (mudharib) 
b. Pembiayaan Musyarakah

Pembiayaan musyarakah adalah perjanjian diantara para pemilik dana/modal untuk mencampurkan dana/modal mereka pada suatu usaha tertentu dengan pembagian keuntungan di antara pemilik dana/modal berdasarkan nisbah yang telah disepakati.

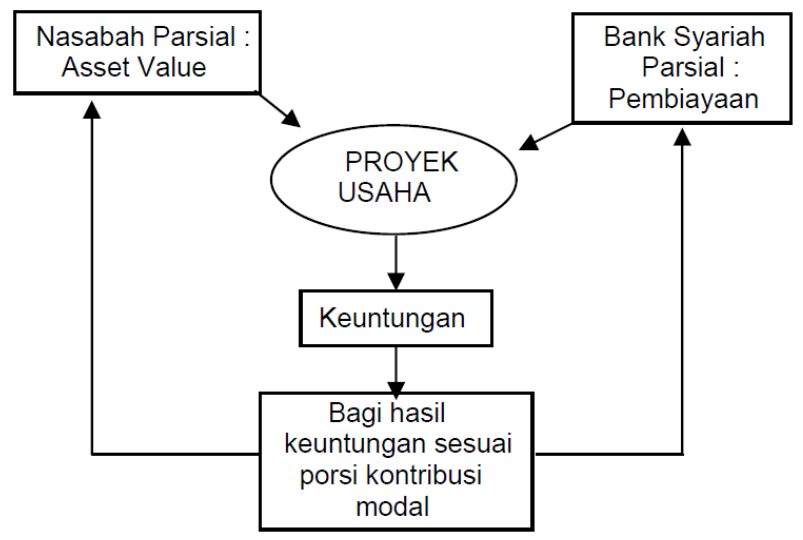

Gambar 2.2 Skema Pembiayaan Musyarakah

Prinsip bagi hasil berdasar perjanjian al musyarakah sebagaimana tersebut diatas, menunjukkan suatu hubungan hukum antara dua pihak yaitu pihak bank (shahibul maal) sebagai penyedia dana dengan mitra usaha (mudharib) sebagai pihak pengelola dana. Hubungan hukum tersebut akan menimbulkan akibat hukum yaitu adanya hak dan kewajiban maupun tanggung jawab pada masing-masing pihak. Prinsip-prinsip bagi hasil berdasarkan perjanjian al musyarakah, terkait dengan pembiayaan terhadap mitra usaha yaitu dapat tercermin dari hak dan kewajiban masing-masing pihak, yaitu pihak bank (shahibul maal) dengan pihak mitra usaha pengelola dana (mudharib).

\subsection{Usaha Mikro Kecil dan Menengah}

Usaha mikro merupakan usaha mikro adalah usaha produktif yang dimiliki orang per orang dan/atau badan usaha perorangan yang memenuhi kriteria usaha mikro sebagaimana yang diatur dalam udang-undang (UU No. 20 tahun 2008). Kriteria usaha mikro yang dimaksud, yaitu: 1) Memiliki kekayaan bersih paling banyak Rp.50 juta, tidak termasuk tanah dan bangunan tempat usaha, atau 2) Memiliki hasil penjualan tahunan paling banyak Rp.300 juta. Pengertian lain dikemukakan Sumitro (2004), usaha mikro kecil dan menengah adalah usaha yang dilakukan oleh suatu perusahaan dengan tenaga kerja yang digunakan tidak melebihi dari 50 orang. Usaha skala mikro merupakan sebagian besar dari bentuk usaha mikro dan usaha kecil misalnya pedagang kaki lima, kerajinan tangan, usaha souvenir, dan sejenisnya.

Usaha Kecil adalah usaha ekonomi produktif yang berdiri sendiri, yang dilakukan oleh orang perorangan atau badan usaha yang bukan merupakan anak perusahaan atau bukan cabang perusahaan yang dimiliki, dikuasai, atau menjadi bagian baik langsung maupun tidak langsung dari usaha menengah atau usaha besar yang usaha yang memiliki asset lebih dari Rp. 50 juta sampai dengan Rp. 500 juta 
dan atau memiliki omset penjualan lebih dari Rp. 300 juta sampai dengan Rp. 2,5 milyar. Usaha menengah adalah usaha ekonomi produktif yang berdiri sendiri, yang dilakukan oleh orang perseorangan atau badan usaha yang bukan merupakan anak perusahaan atau cabang perusahaan yang dimiliki, dikuasai, atau menjadi bagian baik langsung maupun tidak langsung dengan usaha kecil atau usaha besar yang usaha yang memiliki asset lebih dari Rp. 500 juta sampai dengan Rp. 10 milyar juta dan atau memiliki omset penjualan lebih dari Rp. 2,5 milyar sampai dengan Rp. 50 Milyar. Keberadaan usaha menengah dalam konstelasi perekonomian nasional memiliki arti penting dan sangat strategis untuk menjembatani ketimpangan penguasaan aset-aset ekonomi, antara usaha besar dengan usaha kecil dan mikro. Sebab, posisinya dalam berbagai sisi berada antara pengusaha besar dan pengusaha kecil/mikro.

\section{METODE PENELITIAN}

Jenis penelitian yang digunakan adalah penelitian kualitatif.Sedangkan dengan pendekatan multi case studies. Studi multikasus adalah rancangan penelitian yang mengkaji dua atau lebih subjek, latar atau tempat penyimpanan data penelitian. Bogdan dan Biklen (1982) menyebutkan bahwa tatkala peneliti mempelajari dua bidang atau lebih atas penyimpanan data, peneliti biasanya menggunakan apa yang kita sebut studi multi kasus. multi case studies mempunyai berbagai ragam bentuk, beberapa diantaranya memulai dengan hanya satu kasus untuk memiliki pekerjaan utama sebagai seri pertama dalam penelitian atau sebagai pemandu (pilot) untuk studi multi kasus. Tahapan penelitian yang dilakukan melakukan studi lapangan/survei digunakan untuk menemukan mengungkap, mengurai permasalahan pembiayaan sistem bagi hasil di UMKM dan mitra kerjanya, Bank Jatim Syariah, Bank BRI Syariah, Koperasi Syariah dan Baitul Maal Wat Tamwil.

Data yang diperoleh dari penelitian ini merupakan data kualitatif hasil wawancara dan catatan lapangan bulan Maret 2017. Setelah data-data ini diperoleh peneliti, maka akan dilakukan analisis data menggunakan pendekatan deskriptif, di mana peneliti mengdeskripsikan arti data yang telah terkumpul dengan memberikan perhatian dan merekam sebanyak mungkin aspek situasi yang diteliti pada saat itu. Adapun tahapan-tahapan analisis data dalam penelitian ini sesuai dengan analisis data kualitatif model Miles dan Huberman (1992) dalam Sugiyono (2010, 91), yaitu sebagai berikut:

a. Pengumpulan data, yaitu peneliti mencatat semua data secara objektif dan apa adanya sesuai dengan hasil observasi dan wawancara di lapangan.

b. Reduksi data, yaitu memilih hal-hal pokok yang sesuai dengan fokus penelitian. Reduksi data merupakan sebuah bentuk analisis yang menggolongkan, mengarahkan yang tidak perlu dan mengorganisir data-data yang telah direduksi memberikan gambaran yang lebih tajam tentang hasil pengamatan dan mempermudah peneliti untuk mencarinya sewaktu-waktu diperlukan.

c. Penyajian data, yaitu sekumpulan informasi yang tersusun yang memungkinkan adanya penarikan kesimpulan dan pengambilan tindakan. Penyajian data merupakan analisis dalam bentuk matrik, network atau grafis sehingga dapat dikuasai. 
d. Pengambilan keputusan atau verifikasi, berarti bahwa setelah data disajikan, maka dilakukan penarikan kesimpulan atau verifikasi. Untuk itu diusahakan mencari pola, model, tema, hubungan, persamaan dan sebagainya. Jadi, dari data tersebut berusaha diambil kesimpulan. Verifikasi dapat dilakukan dengan keputusan yang didasarkan pada reduksi data dan penyajian data yang merupakan jawaban atas masalah yang diangkat dalam penelitian.

\section{Hasil dan Pembahasan}

Lembaga keuangan syariah dalam pertimbangannya untuk memberikan pembiayaan sistem bagi hasil juga melihat dari kondisi usaha yang akan dijalankan oleh calon mitra usahanya, hal tersebut dapat dilihat dari laporan keuangan dari mitra usahanya. Meskipun setiap lembaga keuangan syariah juga memiliki pertimbangan dalam menganalisa laporan keuangan mitra usaha tetapi terdapat perbedaan diantara masing-masing lembaga keuangan syariah dalam mengambil kebijakan, tidak seluruh lembaga keuangan syariah meminta laporan keuangan mitra usahanya secara lengkap. Rata-rata laporan keuangan yang diminta adalah laporan laba rugi dan laporan posisi keuangan dari mitra usahanya karena cara bagi hasil yang dilakukan oleh masing-masing lembaga keuangan syariah juga berbeda, ada beberapa lembaga yang menggunakan cara laba kotor dibagi atau dengan cara penjualan dibagi atau juga laba bersih dibagi. Lembaga keuangan syariah menjalankan fungsi yang sama dengan lembaga keuangan konvensional, yaitu sebagai lembaga intermediasi (penyaluran), dari nasabah pemilik dana (shahibul mal) dengan nasabah yang membutuhkan dana. Namun, nasabah dana dalam bank syariah diperlakukan sebagai investor dan/atau penitip dana. Dana tersebut disalurkan perbankan syariah kepada nasabah pembiayaan untuk beragam keperluan, baik produktif (investasi dan modal kerja) maupun konsumtif. Dari pembiayaan tersebut, bank syariah akan memperoleh bagi hasil/marjin yang merupakan pendapatan bagi bank syariah. Jadi, nasabah pembiayaan akan membayar pokok + bagi hasil/marjin kepada bank syariah. Pokok akan dikembalikan sepenuhnya kepada nasabah dana sedangkan bagi hasil/marjin akan dibagi hasilkan antara bank syariah dan nasabah dana, sesuai dengan nisbah yang telah disepakati. Artinya dalam bank syariah, dana dari nasabah pendanaan harus di'usahakan' terlebih dahulu untuk menghasilkan pendapatan. Pendapatan itulah yang akan dibagi hasilkan untuk keuntungan bank syariah dan nasabah dana.Setelah dilakukan penelitian terhadap 4 lembaga keuangan syariah terdapat beberapa informasi yang dapat dianalisis yang pertama mengenai persentase pembiayaan yang diberikan oleh 4 lembaga keuangan syariah. Persentase pembiayaan yang diberikan oleh 4 lembaga keuangan syariah tersebut sudah sesuai dengan Peraturan Bank Indonesia Nomor 14/22/PBI/2012 Tentang Pemberian Kredit Atau Pembiayaan Oleh Bank Umum Dan Bantuan Teknis Dalam Rangka Pengembangan Usaha Mikro, Kecil, Dan Menengah Pasal 2 Ayat 3c yang menyebutkan "tahun 2015: rasio Kredit atau Pembiayaan UMKM terhadap total Kredit atau Pembiayaan paling rendah 5\% (lima persen)".

Kedua mengenai alokasi persentase pembiayaan yang diberikan untuk masingmasing pembiayaan bagi hasil yakni pembiayaan mudharabah dan musyarakah, untuk hal tersebut tidak ada ketentuan yang mengikat artinya alokasi persentase pembiayaan tergantung dari fokus atau target dari masing-masing lembaga keuangan syariah dalam menjalankan bisnis usahanya.Ketiga mengenai jenis pembiayaan yang ditujukan untuk UMKM yang jelas adalah untuk modal kerja karena sesuai dengan 
wawancara yang telah dilakukan sebagian besar UMKM membutuhkan tambahan modal dari pembiayaan bagi hasil untuk mengambangkan usahanya. Menurut Antonio (2010), pembiayaan modal kerja yaitu pembiayaan yang mempunyai tujuan untuk memenuhi kebutuhan: peningkatan produksi baik secara kuantitatis (jumlah produksi) maupun secara kualitas (mutu hasil produksi); untuk keperluan perdagangan atau peningkatan utility of place dari suatu barang. Keempat mengenai sektor usaha, sebagian besar pembiayaan yang diberikan oleh 4 lembaga keuangan syariah tersebut ditujukan pada sektor usaha jasa dan sektor usaha perdagang yang pada dasarnya UMKM menjalankan usahanya pada kedua sektor tersebut.Kelima mengenai cara bagi hasil, dari 4 lembaga tersebut memiliki cara masing-masing dalam menentukan bagi hasil. BMT UGT Sidogiri menggunakan cara bagi hasil dengan laba kotor dibagi, sedangkan BRI Syariah dan KUD Trikarsa Jaya menggunakan cara bagi hasil dengan laba bersih dibagi, sedangkan Bank Jatim Syariah menggunakan cara bagi hasil dengan penjualan dibagi. Menurut Anshori (2018, 138) "metode perhitungan bagi hasil terdiri dari metode profit and loss sharing, metode profit sharing dan metode revenue sharing".

Keenam yaitu mengenai syarat dari pengajuan pembiayaan yang dilakukan oleh UMKM, secara keseluruhan 3 dari 4 lembaga keuangan syariah dalam memberikan pelayanan pembiayaan skema bagi hasil mengharuskan calon mitra usahanya membuat laporan keuangan sebagai syarat dalam mengajukan pembiayaan bagi hasil. Tentunya tidak seluruh unsur dari laporan keuangan digunakan sebagai syarat melainkan hanya beberapa laporan keuangan yang dirasa perlu seperti Laporan Laba Rugi dan Laporan Posisi Keuangan, kecuali Koperasi Syariah Tri Karsa Jaya yang tidak mengharuskan calon mitra usahanya membuat laporan keuangan dalam mengajukan pembiayaan, hal ini disadari oleh pihak Koperasi karena sebagian besar mitra usahanya tidak memiliki pengetahuan mengenai cara membuat laporan keuangan sehingga ketika mengajukan pembiayaan tidak memberatkan para calon mitra usahanya.

Produk pembiayaan dari lembaga keuangan syariah dengan skema bagi hasil memiliki banyak manfaat bagi UMKM, berdasarkan hasil wawancara pada 4 lembaga keuangan syariah ada beberapa manfaat dari pembiayaan yang diberikan kepada UMKM, antara lain:

1. Mempermudah dalam memperoleh tambahan modal usaha

2. Pembiayaan sistem bagi hasil lebih adil dan transparan dalam pelaksanaan operasionalnya karena akad diawal sudah jelas dan dengan kesepakatan bersama mitra usaha

3. Pembiayaan sistem bagi hasil usaha nasabah lebih termonitoring

4. Dapat menyesuaikan dengan karakteristik usaha nasabah

Pembiayaan menggunakan prinsip skema bagi hasil yang diberikan oleh lembaga keuangan syariah kepada UMKM memiliki beberapa permasalahan dalam pelaksanaan operasional pembiayaan, sama halnya dengan pihak UMKM sebagai mitra usaha juga mengalami permasalahan dalam melaksanakan pembiayaan dengan skema bagi hasil. Secara keseluruhan setelah dilakukan wawancara mengenai permasalahan yang dihadapi oleh UMKM dan lembaga keuangan syariah sebagai mitra kerjanya. Berikut ini merupakan solusi dari permasalahan yang dihadapi oleh UMKM dan Lembaga Keuangan Syariah sebagai mitra kerjanya: 
a. Minimnya Laporan Keuangan UMKM

Laporan keuangan yang digunakan sebagai syarat dalam mengajukan pembiayaan pada lembaga keuangan syariah menjadi hal yang sangat penting, dikarenakan laporan keuangan merupakan suatu instrumen yang digunakan lembaga keuangan syariah untuk melihat kelayakan suatu usaha yang akan diberikan pembiayaan. Dari laporan keuagan tersebut dapat dilihat besar kecilnya usaha yang berjalan, dan juga dapat dilihat potensi usaha yang dijalankan oleh calon mitra usahanya dan bisa juga dilihat resiko yang akan dihadapi lembaga keuangan syariah apabila memberikan pembiayaan. Sesuai dengan Undang-Undang Nomor 10 tahun 2008 tentang Perbankan menyatakan: "Untuk mengurangi risiko tersebut, jaminan pemberian kredit atau pembiayaan berdasarkan prinsip syariah dalam arti keyakinan atas kemampuan dan kesanggupan nasabah debitur untuk melunasi kewajibannya sesuai dengan diperjanjikan merupakan faktor penting yang harus diperhatikan oleh bank. Untuk memperoleh keyakinan tersebut, sebelum memberikan kredit, bank harus melakukan penilaian yang saksama terhadap watak, kemampuan, modal, agunan dan prospek usaha dari nasabah debitur. Mengingat bahwa agunan sebagai salah satu unsur pemberian kredit, maka apabila berdasarkan unsurunsur lain telah diperoleh keyakinan, agunan dapat hanya berupa barang, proyek, atau hak tagih yang dibiayai dengan kredit yang bersangkutan”.

UMKM yang pada umumnya dijalankan oleh masyarakat menengah kebawah masih minim dalam hal pencatatan maupun pelaporan keuangan dari usahanya, karena pendidikan dari pengusaha UMKM masih rendah dan kebanyakan masih belum memahami aturan-aturan dalam pembuatan laporan keuangan sehingga laporan keuangan yang dihasilkan oleh UMKM masih sangat terbatas dan sistematikanya masih tradisional karena tidak sesuai dengan standar laporan keuangan pada umumnya. Untuk mengatasi masalah tersebut dapat dilakukan pembinaan dan pendampingan UMKM dalam membuat laporan keuangan, hal tersebut dilakukan agar lembaga keuangan syariah lebih berperan kepada mitra usahanya dan dari pihak UMKM juga merasa terbantu dengan adanya pembinaan dan pendampingan dalam membuat laporan keuangan. Semakin baik laporan keuangan yang dibuat akan semakin baik juga usaha yang dijalankan karena dengan menggunakan laporan keuangan, UMKM akan lebih mudah dalam mengajukan pembiayaan dalam rangka menambah modal usaha.

\section{b. Side Streaming}

Side streaming adalah istilah lain dari perbuatan penyalahgunaan fasilitas kredit yang didapatkan dari perbankan atau nasabah menggunakan dana tersebut bukan seperti dalam kontrak, lalai dan kesalahan yang disengaja, penyembunyian keuntungan oleh nasabah bila nasabahnya tidak jujur. Hal tersebut menjadi permasalahan yang dihadapi oleh lembaga keuangan syariah, salah satunya dihadapi oleh Bank Syariah Mandiri. Pembiayaan sistem bagi hasil yang diperoleh UMKM dari lembaga keuangan syariah yang pada awal akadnya digunakan modal kerja tetapi setelah mendapat pembiayaan digunakan untuk hal-hal yang konsumtif, hal tersebut dapat merugikan pihak lembaga keuangan syariah karena ketika pembiayaan terebut digunakan tidak sesuai dengan usahanya maka rentan terjadinya kerugian dan kemudian kerugian tersebut ditanggung oleh pihak lembaga keuangan syariah. Karena pada 
dasarnya ketika suatu usaha yang dibiayai ketika terdapat keuntungan akan dibagi sesuai nisbah yang disepakati dan ketika terjadi kerugian maka akan ditanggung oleh pihak yang memberikan pembiayaan.

Untuk menghindari atau mengatasi masalah tersebut dapat dilakukan berbagai cara dari pihak lembaga keuangan syariah yaitu yang pertama adanya monitoring yang dilakukan secara berkala pada mitra usahanya baik dari segi usahanya maupun dari segi hasil usaha yang dicapai oleh mitra usaha melalui laporan keuangannya. Solusi yang kedua untuk pihak lembaga keuangan syariah yaitu dapat diberkan sanksi kepada mitra usahanya apabila melakukan side streaming, dan sanksi tersebut di informasikan pada awal ketika pengajuan pembiayaan oleh UMKM. Ketiga meningkatkan pemahaman masyarakat mengenai budaya kejujuran dan produk pembiayaan bank syariah. Perilaku atau perangai masyarakat yang dikhawatirkan oleh perbankan syariah tersebut di dalam sosiologi hukum telah disebutkan. Perilaku tidak jujur masyarakat dalam objek kajian sosiologi hukum disebut dengan behavior, yatu merupakan kenyataan hukum di masyarakat yang terkadang terjadi tidak sesuai dengan apa yang diharapkan.

c. Asimetri Informasi

Asimetri informasi yaitu kondisi dimana salah satu pihak menguasai informasi lebih baik dibandingkan dengan pihak lainnya, atau salah satu pihak tidak memiliki informasi yang sama dengan pihak lainnya. Dalam permasalahan ini yang dimaksud adalah pihak lembaga keuangan syariah ketika nasabah mengajukan pembiayaan tidak mendapatkan pemahaman yang cukup mengenai hal-hal yang terkait dengan pembiayaan sehingga dapat menimbulkan salah persepsi dari informasi yang diterima.

Untuk mengatasi permasalahan tersebut, pihak lembaga keuangan syariah harus melakukan peningkatan kualitas dan kuantitas Sumber Daya Insani lembaga keuangan syariah syariah. Bagi lembaga keuangan syariah, maka pengembangan sumber daya insani tidak hanya memerlukan pengetahuan yang luas di bidang perbankan, memahami implementasi prinsip-prinsip syariah di dalam praktiknya, namun juga memiliki komitmen yang kuat untuk menerapkannya secara konsisten.

\section{Kesimpulan, Keterbatasan, Saran}

Secara keseluruhan dari 4 lembaga keuangan syariah memiliki pembiayaan sistem bagi hasil yaitu pembiayaan mudharabah dan pembiayaan musyarakah sebagai salah satu produk dari lembaga keuangan syariah dalam memberikan pelayanan kepada mitra usahanya. Persentase pembiayaan yang diberikan oleh 4 lembaga keuangan syariah tersebut sudah sesuai dengan Peraturan Bank Indonesia Nomor 14/22/PBI/2012 Tentang Pemberian Kredit Atau Pembiayaan Oleh Bank Umum Dan Bantuan Teknis Dalam Rangka Pengembangan Usaha Mikro, Kecil, Dan Menengah Pasal 2 Ayat 3c yang menyebutkan tahun 2015: rasio Kredit atau Pembiayaan UMKM terhadap total Kredit atau Pembiayaan paling rendah 5\% (lima persen). Mengenai cara bagi hasil, dari 7 lembaga tersebut memiliki cara masingmasing dalam menentukan bagi hasil. BMT UGT Sidogiri menggunakan cara bagi hasil dengan laba kotor dibagi, sedangkan BRI Syariah dan KUD Trikarsa Jaya menggunakan cara bagi hasil dengan laba bersih dibagi, sedangkan Bank Jatim Syariah menggunakan cara bagi hasil dengan penjualan dibagi. 
Masih ada beberapa permasalahan yang dihadapi dalam pelaksanaan pemberian pembiayaan bagi hasil misalnya kurangnya informasi tentang laporan keuangan, adanya side streamingdan asimetri informasi. Solusi yang dapat diberikan penulis secara umum adalah dengan melalui pendekatan kepada mitra kerja agar lebih memahami prosedur yang diberikan oleh pemberi modal. Pada proses penelitian ini, juga ada beberapa keterbatasan antara lain: (1) Faktor subjektifitas peneliti dalam memberikan penjelasan dalam penelitian; (2) Objek penelitian kurang terbuka dalam memberikan informasi, sehingga ada beberapa informasi yang kurang lengkap; dan (3) Banyaknya objek penelitian menjadikan penelitian ini kurang fokus pada permasalahan, sehingga peneliti tidak dapat menggali lebih dalam permasalahan yang terdapat pada penelitian ini.

\section{DAFTAR PUSTAKA}

Adiwarman, K. 2004. Bank Islam: Analisis Fiqih dan Keuangan. Jakarta: PT. Raja Grafindo.

Anshori, A. G. 2018. Hukum perjanjian Islam di Indonesia: konsep, regulasi, dan implementasi: UGM PRESS.

Antonio, M. S. i. 2001. Bank Syariah: dari teori ke praktik: Gema Insani.

Antonio, M. S. i. 2010. Ekonomi Syariah dari Teori ke Praktek: Gema Insani: Jakarta.

Bogdan, R., dan S. Biklen. 1982. Methods of social research: Boston: Allyn and Bacon Inc.

Miles, M. B., dan A. M. Huberman. 1992. Analisis data kualitatif: Jakarta: UI press.

Siddiqui, U., H. Patel, J. Mastrototaro, L. Fredrickson, K. Holtzclaw, B. Wenholz, M. Estes, dan F. Saidara. 2005. System for monitoring physiological characteristics: Google Patents.

Sugiyono, D. 2010. Metode penelitian kuantitatif kualitatif dan R\&D. xiii.

Sumitro, W. 2004. Asas-asas Perbankan Islam dan lembaga-lembaga Terkait. Jakarta: Raja Grafindo Persada 119.

Susilo, Y. 2012. Strategi meningkatkan daya saing UMKM dalam menghadapi implementasi CAFTA dan MEA. Buletin Ekonomi.

Syafi'i, M. A. 2005. Perbankan Syariah dan Teori Kepraktikan. Jakarta: Gema Insan.

Triyuwono, I. 2004. THE ISLAMIC PERSPECTIVE ON THE CONSTRUCTION OFACCOUNTING DISCIPLINE. Gadjah Mada International Journal of Business 6 (1):131-149.

Peraturan Bank Indonesia Nomor 14 Tahun /2012 Tentang Pemberian Kredit Atau Pembiayaan Oleh Bank Umum Dan Bantuan Teknis Dalam Rangka Pengembangan Usaha Mikro, Kecil, Dan Menengah

Undang-Undang Republik Indonesia Nomor 10 tahun 2008 tentang Perbankan

Undang-Undang Republik Indonesia Nomor 20 Tahun 2008Tentang Usaha Mikro, Kecil dan Menengah (UMKM).

Undang-Undang Republik Indonesia Nomor 10 tahun 2008 tentang Perbankan

Yumanita, Ascarya Diana, 2005. Mencari Solusi Rendahnya Pembiayaan Bagi-Hasil Di Perbankan Syari'ah Indonesia.Buletin Ekonomi Moneter dan Perbankan : 8-50. Jakarta: Bank Indonesia. http//www.bi.go.id/ 